\title{
Induced Morphological Changes in Larval Rock Bream, Oplegnathus fasciatus, under Starvation
}

\author{
${ }^{\dagger}$ In-Seok Park', Hee-Jung Choi ${ }^{2}$, Choong-Hwan Noh ${ }^{3}$, Jung-Goo Myoung', \\ Hye Jung Park ${ }^{1}$ and In Bon Goo ${ }^{1}$ \\ ${ }^{1}$ Division of Marine Environment and Bioscience, College of Ocean Science and Technology, \\ Korea Maritime and Ocean University, Busan 606-791, Republic of Korea \\ ${ }^{2}$ Tong-Yeong Marine Living Resources Research \& Consevation Center, \\ Korea Institute of Ocean Science \& Technology (KIOST), Ansan 426-744, Republic of Korea \\ ${ }^{3}$ East Sea Environment Research Division, KIOST, Ansan 426-744, Republic of Korea
}

\begin{abstract}
Morphological changes in the reared rock bream, Oplegnathus fasciatus, from hatching to six days after hatching were examined during the early growth stage under starvation. All the larvae died within five days when feeding was delayed for three days after hatching. These results imply that initial larval food should be supplied within two days of hatching. Changes in the pectoral angle and the ratios of eye height to head height, gut height to standard length, and gut height to myotome height in the rock bream are alternative indicators for the identification of starving fish. These indicators might prove useful in evaluating the successful transition from endogenous to exogenous feeding in this species.
\end{abstract}

Key words : Feeding regime, Growth, Indicator, Rock bream, Starvation

\section{INTRODUCTION}

The time line from hatching to the first food intake can vary according to (1) developmental capacity, (2) efficiency in using the yolk food supply, and (3) internal functions related to food storage (Park \& Zhang, 1998; Rust, 2002). Many fish undergo natural periods of starvation, which may be seasonal but are not always. Fish, like other vertebrates, can reduce their energy demand during food deprivation, sometimes by lowering their average metabolic rate during such periods (Johnson, 1989). Fish starvation studies are significant in determining the fish's nutritional and growth characteristics (Love, 1980). Many fish species undergo natural periods of starvation during the year, and have consequently evolved the capacity to withstand prolonged food shortages. Such periods may extend from weeks, months, to even years, and may cause extensive loss of energy stores in the body of the fish consumes its own tissues to remain alive (Weatherley \& Gill, 1987).

The success of feeding and the ability to avoid predators in the period after hatching are likely to be partly affected by the initial size and activity of the larvae, as well as by the capacity of the yolk reserve to meet their metabolic demands (Blaxter \& Hempel, 1963). If fish do not have on-time access to their first feed after hatching, they quickly exhaust their endogenous stored energy and

\footnotetext{
Manuscript received 23 November 2013, Received in revised form 10 December 2013, Accepted 15 December 2013

† Corresponding Author : In-Seok Park, Division of Marine Environment and Bioscience, College of Ocean Science and Technology, Korea Maritime and Ocean University, Busan 606-791, Republic of Korea. Tel. : +82-51-410-4321, Fax : +82-51-405-4322; E-mail : ispark@kmou.ac.kr

This is an Open Access article distributed under the terms of the Creative Commons Attribution Non-Commercial License (http://creativecommons. org/licenses/by-nc/3.0) which permits unrestricted non-commercial use, distribution, and reproduction in any medium, provided the original work is properly cited.
} 
lose the ability to swim and find food, thus reaching the point of no return (PNR) (Blaxter \& Hempel, 1963). Fish larvae can survive during the fish passing PNR mortality (Myong et al., 1992).

Morphological differences in groups and species are classified in terms of the overall body shape or specific morphoanatomical characteristics (Han et al., 2013). Among the body shape characteristics of fish, morphometric traits, unlike meristic traits, can be measured as mensural characteristics. Although the body shape of fish is largely determined by genetic factors (Lim et al., 2013), the use of morphometric analyses to distinguish genetically discrete groups within a fish species is limited by the difficulty of measuring environmentally induced variations in body shape (Han et al, 2013; Lim et al., 2013).

The rock bream, Oplegnathus fasciatus (Temminck et Schlegel), is widely distributed across the rocky coastal regions of Korea, Japan, Taiwan, and Hawaii (Choi et al., 2002). When they are fry in the shade of drifting seaweed, they mainly eat zooplankton, and when they are grown, they move to the bottom of the sea to live on the sea floor (Choi et al., 2002). When their total length is about $10 \mathrm{~cm}$, they become polyphagic (Choi et al., 2002). The rock bream is relatively easy to mass produce with artificial seeding, so they are a good candidate for aquaculture (Hwang et al., 1996; Kang et al., 1998; Kim et al., 2002).

There is a paucity of data on specific aspects of rock bream breeding and growth, including physiological information on larval survival. The identification in planktonic samples of fish larvae that are starving would be a valuable aide to estimating the early mortality rates of populations in the sea. The early survival rate of marine fish is determined by the PNR, which is the point at which fish must find external nutrients after exhausting their internal nutrient source (the yolk) (O'Connell, 1976; Theilacker, 1978; Strüssmann \& Takashima, 1990; Park et al., 1998; Lee et al., 1998). Shan et al. (2008) previously reported that effects of delayed first feeding on growth and survival of rock bream. In this study, we focus on morphological changes in rock bream larvae to starvation and investigated their yolk absorbance.

\section{MATERIALS AND METHODS}

To conduct a starvation experiment on the larvae of the rock bream, Oplegnathus fasciatus, eggs were hatched and the fry were then separated into approximately 500 fish per tank (volume: 20 tons). The fed group was given cultured rotifers, Israchionus plicatilis, whereas the unfed group was unfed. The water temperature was $24.0^{\circ} \mathrm{C}$, the dissolved oxygen $6.5 \mathrm{ppm}$, and the specific gravity 1,023.

The termination point of the experiment was determined when the specimens exhibited an abrupt reduction in vitality. The survival rate was ascertained from the time the larvae were exposed to starvation. Every day, 20 larvae were extracted from each tank and fixed in neutral formalin (100 ml of formalin, $6.5 \mathrm{~g}$ of $\mathrm{Na}_{2} \mathrm{HPO}_{4} \cdot 12 \mathrm{H}_{2} \mathrm{O}$, $4.5 \mathrm{~g}$ of $\mathrm{KH}_{2} \mathrm{PO}_{4}$ in $900 \mathrm{ml}$ of distilled water) for 24 $\mathrm{h}$, after which their morphometric traits were measured using a biological microscope (Axiostar Plus, Carl Zeiss, Germany) with an eyepiece micrometer for compared with the morphological difference (Fig. 1).

The experiment was performed in triplicate. To study the size and changes in the yolk structure, the yolk size was examined in the fed and starvation groups. The size of the yolk was calculated and measured according to the method described by Blaxter \& Hempel (1966): yolk size $=(\pi / 6) \times \mathrm{LW}^{2}$ (L: length of yolk; W: width of yolk).

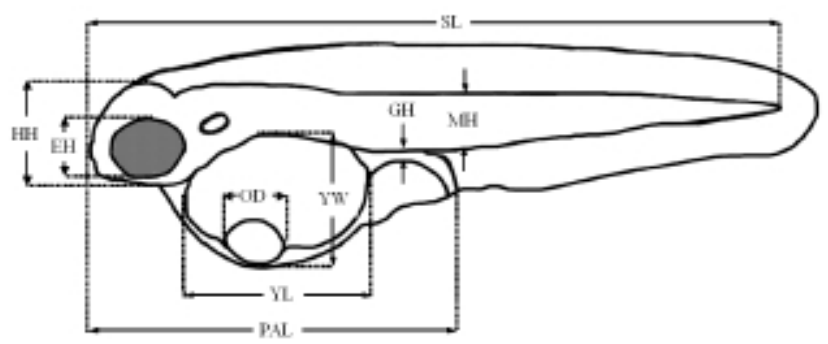

Fig. 1. Dimensions of the larval rock bream, Oplegnathus fasciatus. $\mathrm{EH}$, eye height; $\mathrm{GH}$, gut height; $\mathrm{HH}$, head height; $\mathrm{MH}$, myotome height; OD, oil globule diameter; PAL, preanal length; SL, standard length; YL, yolk sac length; YW, yolk sac width. 
We also examined the increase in the standard length, the percentage of eye height/head height, the percentage of preanal length/standard length, the percentage of gut height/standard length, the percentage of arthromere height/ standard length, the percentage of gut height/arthromere height, and the pectoral angle during starvation.

\section{RESULTS}

The larvae of the rock bream, Oplegnathus fasciatus, in the unfed group were all dead after five days from hatching, coincident with an abrupt loss of vitality (Fig. 2). Fig. 2 shows that the survival of the fed group was $84 \%$ six days after hatching, whereas that of the unfed group was $93.1 \%$ two days after hatching, $67.1 \%$ at three days, $50.0 \%$ at four days, and zero on the 5th day. The yolk of the unfed group was completely absorbed by the third day, whereas absorption of the yolk and the oil globule diameter were completed in the fed group four days after thatching (Table 1).

The increase in the standard length (SL) of the fed group was $3.0 \pm 0.12 \mathrm{~mm}$, and it grew constantly, reaching in $4.9 \pm 0.27 \mathrm{~mm}$ six days after hatching. In contrast, the SL of the unfed group was $3.0 \pm 0.20 \mathrm{~mm}$ after four days, and it had decreased to $2.7 \pm 0.18 \mathrm{~mm}$ five days after hatching (Fig. 3). The ratio of eye height/head height in the fed group was $51.4 \pm 3.27 \%$ after hatching and remained constant (50.2-53.1\%) for six days after hatching (Fig.

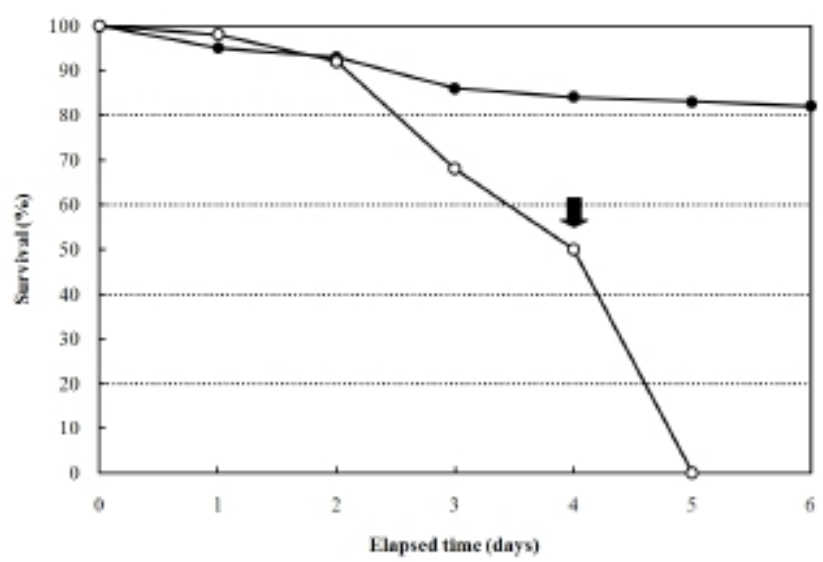

Fig. 2. Survival curves for larval rock bream, Oplegnathus fasciatus during starvation with age. Closed circle: survival of fed larvae; open circle: survival of starved larvae. Arrow shows the point of no return when this occurred within the experimental period. The experiment was performed in triplicate.

4). However, the ratio of eye height/head height increased after hatching in the unfed group, reaching $83.2 \pm 0.68 \%$ after six days (Fig. 4).

Fig. 5 shows the changes in the preanal length/standard length, gut height/standard length, and myotome height/ standard length ratios. The ratio of preanal length/standard length after hatching was $53.8 \pm 0.32 \%$, and decreased continually in the fed group to $47.0 \pm 0.39 \%$ after six days. The unfed group showed a larger reduction in the preanal length/standard length ratio compared with the fed group, with a ratio of $30.1 \pm 0.31 \%$ after five days. The ratio of gut height/standard length was $3.7 \pm 0.12 \%$ after hatching,

Table 1. Yolk resorption and change of oil globule diameter in rock bream, Oplegnathus fasciatus during starvation with age*

\begin{tabular}{|c|c|c|c|c|c|c|c|c|}
\hline \multirow{3}{*}{$\begin{array}{c}\text { Days } \\
\text { after } \\
\text { hatching }\end{array}$} & \multicolumn{6}{|c|}{ Yolk sac } & \multirow{2}{*}{\multicolumn{2}{|c|}{$\begin{array}{c}\text { Oil globule } \\
\text { diameter }(\mu \mathrm{m})\end{array}$}} \\
\hline & \multicolumn{2}{|c|}{ Width $(\mu \mathrm{m})$} & \multicolumn{2}{|c|}{ Length $(\mu \mathrm{m})$} & \multicolumn{2}{|c|}{ Volume $\left(\mathrm{mm}^{3}\right)$} & & \\
\hline & $\mathrm{F}$ & $\mathrm{U}$ & $\mathrm{F}$ & $\mathrm{U}$ & $\mathrm{F}$ & $\mathrm{U}$ & $\mathrm{F}$ & $\mathrm{U}$ \\
\hline 0 & $849 \pm 45.7$ & $849 \pm 45.7$ & $1,345 \pm 67.7$ & $1,345 \pm 67.7$ & $0.51 \pm 0.041$ & $0.51 \pm 0.041$ & $197 \pm 10.2$ & $197 \pm 10.2$ \\
\hline 1 & $800 \pm 35.2$ & $801 \pm 40.3$ & $1,242 \pm 43.7$ & $1,240 \pm 51.8$ & $0.41 \pm 0.037$ & $0.42 \pm 0.031$ & $190 \pm 13.7$ & $191 \pm 10.5$ \\
\hline 2 & $702 \pm 30.7$ & $700 \pm 32.6$ & $1,115 \pm 32.9$ & $1,110 \pm 40.7$ & $0.29 \pm 0.018$ & $0.28 \pm 0.020$ & $110 \pm 8.9$ & $111 \pm 10.7$ \\
\hline 3 & $460 \pm 15.0$ & 0 & $900 \pm 25.1$ & 0 & $0.10 \pm 0.005$ & 0 & $106 \pm 5.7$ & 0 \\
\hline 4 & 0 & - & 0 & - & 0 & - & 0 & - \\
\hline
\end{tabular}

*The value are means $\pm \mathrm{SD}(\mathrm{n}=20)$ and the experiment was performed in triplicate. Yolk sac volume $=(\pi / 6) \times \mathrm{LW}^{2}(\mathrm{~L}:$ yolk sac length; W: yolk sac width. After Blaxter \& Hempel, 1966), F: fed group; U: unfed group. 


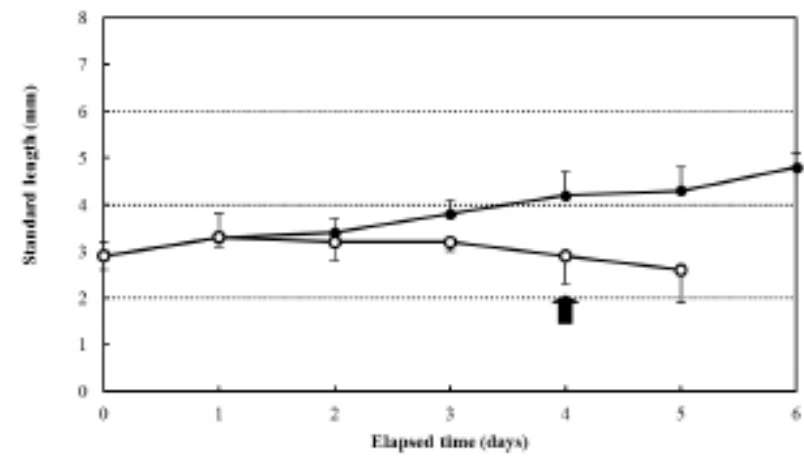

Fig. 3. Growth rate of larval rock bream larvae, Oplegnathus fasciatus, during starvation showing changes with age. Closed circle: growth changes in fed larvae; open circle: changes with starvation. Arrow shows the point of no return when this occurred within the experimental period. The bars are means $\pm \mathrm{SE}$ and the experiment was performed in triplicate.

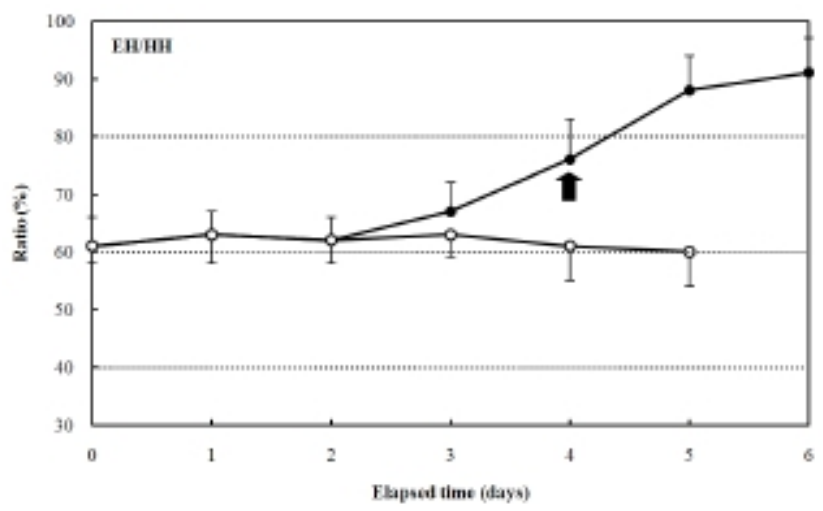

Fig. 4. Ratio of morphometric characters in the larval rock bream, Oplegnathus fasciatus, during starvation with age. Closed circle: ratio changes of fed larvae; open circle: starvation changes. Arrow shows the point of no return when this occurred within the experimental period. The bars are means $\pm \mathrm{SE}$ and the experiment was performed in triplicate. $\mathrm{EH}$ : eye height; $\mathrm{HH}$ : head height.

and $3.4 \pm 0.22 \%$ after six days in the fed group. However, in the unfed group, this ratio was $3.8 \pm 0.23 \%$ two days after hatching and showed a rapidly decreasing trend to $0.8 \pm 0.07 \%$ after five days (Fig. 6).

The ratio of myotome height/standard length after hatching was $4.9 \pm 0.27 \%$, and it was $4.3 \pm 0.39 \%$ in the fed group after six days. In contrast, the unfed group showed a ratio of $5.0 \pm 0.31 \%$ after two days, which had declined to $2.3 \pm 0.20 \%$ five days after hatching. The ratio of gut

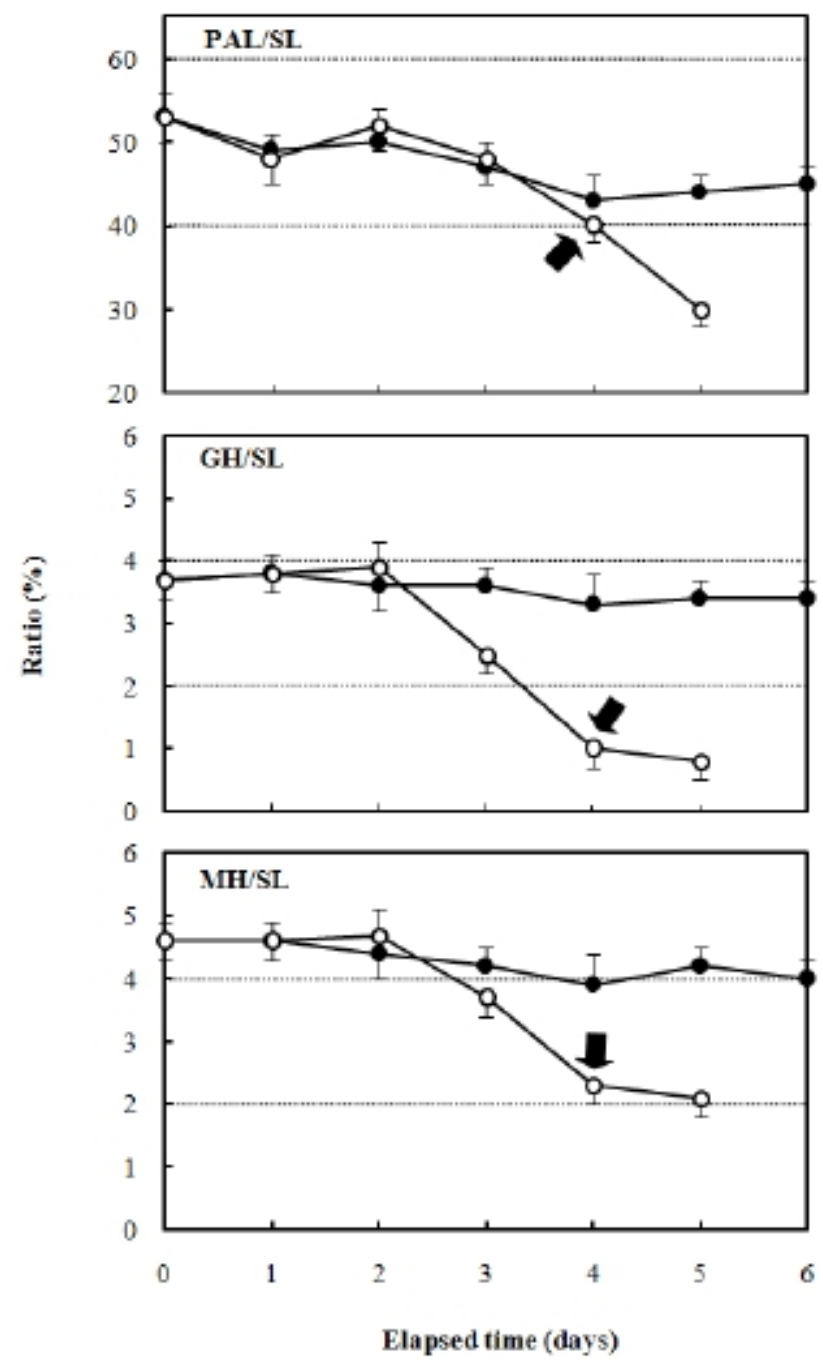

Fig. 5. Ratios of morphometric characters in the larval rock bream, Oplegnathus fasciatus, during starvation with age. Closed circle: ratio changes in fed larvae; open circle: changes in starved larvae. Arrows show the points of no return when they occurred within the experimental period. The bars are means $\pm \mathrm{SE}$ and the experiment was performed in triplicate. GH: gut height; $\mathrm{MH}$ : myotome height; PAL: preanal length; SL: standard length.

height/myotome height after hatching was $75.0 \pm 0.47 \%$ (Fig. 7). In the fed group, this had increased to 78.6 \pm $6.9 \%$ after six days, whereas it was $75.0 \pm 5.27 \%$ in the unfed group after two days, and then declined to $33.3 \pm$ 3.62\% five days after hatching (Fig. 7). The pectoral angle was $160 \pm 11.7^{\circ}$ upon hatching and showed a general reduction to $150 \pm 9.8^{\circ}$ in the fed group after six days (Fig. 8). In contrast, the pectoral angle of the unfed group 


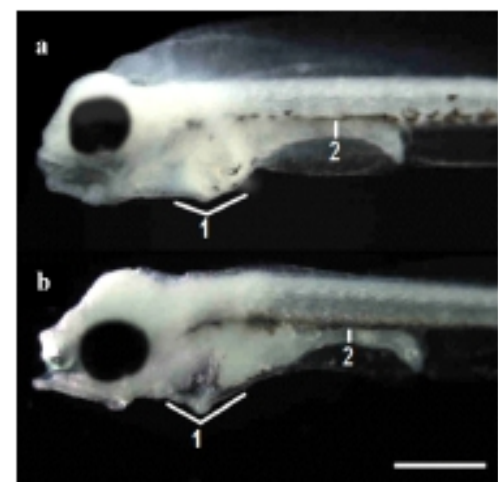

Fig. 6. Four-day-old larval rock bream, Oplegnathus fasciatus. (a) fed, (b) starved to the point of no return. Note the pectoral angle (1) and gut shrinkage (2). Bar is $100 \mu \mathrm{m}$.

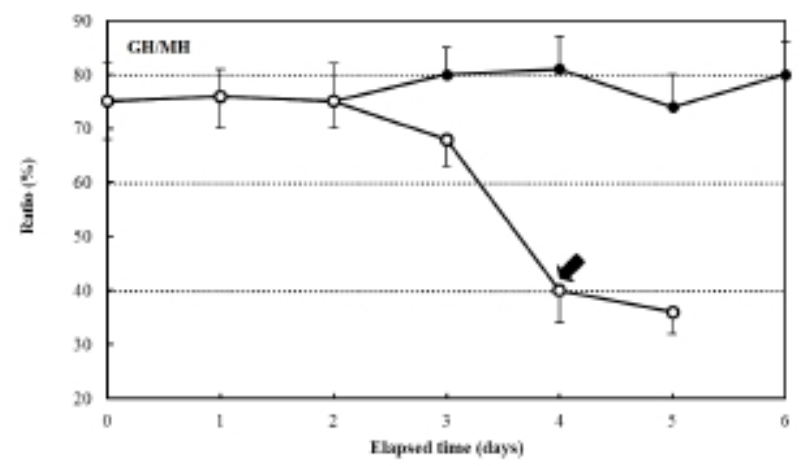

Fig. 7. Ratios of morphometric characters of larval rock bream, Oplegnathus fasciatus, during starvation with age. Closed circle: ratio changes in fed larvae; open circle: ratio changes in starved larvae. Arrow shows the point of no return when this occurred within the experimental period. The bars are means $\pm \mathrm{SE}$ and the experiment was performed in triplicate. GH: gut height; $\mathrm{MH}$ : myotome height.

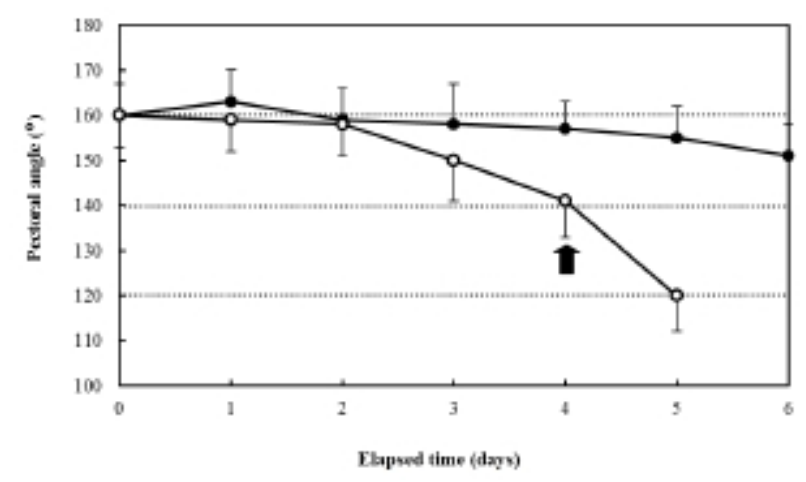

Fig. 8. Pectoral angle of the larval rock bream, Oplegnathus fasciatus, duning starvation with age. Closed circle: pectoral angle changes in fed larvae; open circle: pectoral angle changes in starved larvae. Arrow shows the point of no return when this occurred within the experimental period. The bars are means $\pm \mathrm{SE}$ and the experiment was performed in triplicate. was $120 \pm 8.8^{\circ}$ after five days (Fig. 8).

\section{DISCUSSION}

The period immediately after the absorption of the yolk supply, usually completed within three days after hatching, is critical for fish larvae. This is when a successful transition from inner nutrient intake to external nutrient intake must be made (Farris, 1960). According to Blaxter \& Hempel (1963), approximately 50\% of larvae can begin access an external food supply four days after hatching (Table 2). According to the feeding time and the ability to resist starvation in fish larvae, the feeding patterns were divided into two types: type $\mathrm{A}$, the feeding rate was low at first feeding time, then rapidly increased, followed by a remarkable decrease; and type B, the feeding rate was low at first feeding time, rapidly increased and kept stable for a period of time at the highest feeding rate, and then rapidly decreased. The rock bream belong to type A (Shan et al., 2008).

In order to determine the ability of the fish to resume eating after a period of starvation, the PNR (Point-of-NoReturn) concept has been introduced (Blaxter \& Hempel, 1963). PNR refers to the point at which a state of constantly maintained starvation proves sufficient to prevent exactly $50 \%$ of fries from resuming feeding after a food supply is re-established. PNR is determined via observations of the vitality of fishes, as well as water temperature, which is the principal environmental factor that determines metabolism during starvation. Also, the beginning point of PNR has been measured from both the time of fertilization and the time of yolk absorption, depending on the investigator's objective (Blaxter \& Hempel, 1963; Weatherley \& Gill, 1987).

The rock bream, Oplegnathus fasciatus, has enough yolk supply to survive for two days without feeding. This is similar to the Northern anchovy, Engraulis mordax, whereas the California grunion, Leuresthes tenuis, which has large larvae that hatch from big eggs, can survive for more than eight days before exhausting their yolk 
I-S Park, H-J Choi, C-H Noh, J-G Myoung, HJ Park, IB Goo

Table 2. Vulnerability to starvation at the time of first feeding of nine species*

\begin{tabular}{|c|c|c|c|c|c|}
\hline \multirow{2}{*}{ Species } & \multirow{2}{*}{$\begin{array}{c}\text { Temperature } \\
\left({ }^{\circ} \mathrm{C}\right)\end{array}$} & \multirow{2}{*}{$\begin{array}{l}\text { Length at } \\
\text { hatching }\end{array}$} & \multirow{2}{*}{ Yolk absorption } & \multicolumn{2}{|c|}{ Days to point of no return from } \\
\hline & & & & Yolk absorption & Onset of feeding \\
\hline \multicolumn{6}{|l|}{ California grunion } \\
\hline Leuresthes tenuis & 20 & 9.0 & 4 & 8* & $12 *$ \\
\hline \multicolumn{6}{|l|}{ Atherinidae } \\
\hline \multicolumn{6}{|l|}{ Atlantic herring } \\
\hline Clupea harengus & $7-8$ & 8.2 & 8 & 6 & 22 \\
\hline \multicolumn{6}{|l|}{ Clupeidae } \\
\hline \multicolumn{6}{|l|}{ Haddock } \\
\hline Melanogrammus & 7 & 3.5 & $6-7$ & 0.1 & - \\
\hline \multicolumn{6}{|l|}{ anglefinis Gadidae } \\
\hline \multicolumn{6}{|l|}{ Pacific mackerel } \\
\hline Scomber japonicus & 19 & 3.1 & 3 & 1.0 & 1.6 \\
\hline \multicolumn{6}{|l|}{ Scombridae } \\
\hline \multicolumn{6}{|l|}{ Northen anchovy } \\
\hline Engrulis mordax & 16.5 & 2.9 & 4 & 1.5 & 2.5 \\
\hline \multicolumn{6}{|l|}{ Engraulidae } \\
\hline \multicolumn{6}{|l|}{ Bay anchovy } \\
\hline Anchoa mitchilli & 24 & 2.5 & 1.7 & 1.4 & 1.7 \\
\hline \multicolumn{6}{|l|}{ Engraulidae } \\
\hline \multicolumn{6}{|l|}{ Sea bream } \\
\hline Archosargus rhomboidalis & 22 & 2.3 & 2.2 & 1.2 & 1.7 \\
\hline \multicolumn{6}{|l|}{ Sparidae } \\
\hline \multicolumn{6}{|l|}{ Lined sole } \\
\hline Achirus lineatus & 24 & 1.9 & 3.3 & 0.5 & 1.3 \\
\hline \multicolumn{6}{|l|}{ Soleidae } \\
\hline \multicolumn{6}{|l|}{ Rock bream (Present study) } \\
\hline Oplegnathus fasciatus & 24 & 2.0 & 3 & 1.0 & 1.5 \\
\hline Oplegnathidae & & & & & \\
\hline
\end{tabular}

*Modified from Gerking (1994). Values were taken from several sources and summarized.

supply (May, 1974). According to May (1974), the California grunion can survive a further eight days (16 days in total) of starvation after the exhaustion of its yolk supply before it reaches the PNR. However, the haddock, Melanogrammus aeglefinus, will quickly die if it is not immediately supplied with food after absorbing its yolk (Laurence, 1974). Because water temperature and larval activity are related to increases and reductions in metabolism, the PNR of the black bream, Acanthopagrus schlegeli, is dependent on water temperature (Gerking, 1994). The point of PNR was 4 days after the start of the experiment under starvation conditions with the larval rock bream. PNR was shown to vary due to temperature (Weatherley \& Gill, 1987), and varying PNR points have been determined in various fish species, as indicated in Table 2. Small fries hatching from small eggs, such as the Northern anchovy, or Leuresthes tenuis, can survive only 1 2 days after yolk absorption, but big fries hatching from big eggs, including the California grunion.

If the haddock, rockbream does not feed after complete yolk absorption, the fries will die of starvation, but the fries of the chum salmon survived for 22 days after yolk absorption if they were allowed to feed again during this time (Laurence, 1974; Seong et al., 2012). Because different 
species can survive different periods of starvation, the accumulation of PNR data may facilitate the development of technology allowing for distinctions to be made between good fries and bad fries using the PNR method (Myoung et al., 1997).

The ratio of eye-height/head height in the herring, Clupea harengus, under starvation was $75 \%$, whereas the ratio for plaice, Pleuronectes platessa, under starvation was 60\% (Ehrlich et al., 1976). Starvation induces general reductions in the ratios of preanal length/standard length, gut height/standard length, and myotome height/standard length. These data indicate that the digestive capacities of the gut diminish significantly with a lack of feeding, a condition also reported in the codfish, Gadus morhua, the flounder, Platichthys flesus, the red-sea bream, Pagrus major, and the sea bass, Lateolabrax sp. (Yin \& Blaxter, 1986; Myong et al., 1990, 1992, 1997). According to Crespo et al. (2001), after experimental starvation, atrophy of the larval digestive structures, pancreatic degeneration, and a lack of supranuclear vacuoles in the larval hindgut were observed. The cause of the reduction in the pectoral angle may that the fat tissue responsible for its buoyancy is utilized by the general metabolism, thus making it difficult for the larvae to search for food and ultimately leading to death (Ehrlich et al., 1976).

Our study do an experiment on the increase in the standard length, the ratio of eye height/head height, the ratio of preanal length/standard length, gut height/standard length, and myotome height/standard length, myotome height/ standard length and the ratio of gut height/myotome height after hatching of fed group and unfed group. Shan et al. (2008) reported that the ratio of head height/standard length, eye diameter/standard length, head height/head length, and the ratio of diameter/head length in fed group and unfed group. Shan et al. (2008) mainly focused on differences of development pattern between fed and unfed group. Our study mainly focused on morphological changes between fed and unfed group. Survival rate decrease and PNR were more quickly than Shan et al. (2008), because that different metabolism according to water temperature.
These morphometric traits are effective indicators of the nutritional status of rock bream larvae. These results also confirm that the initial larval food should be supplied within two days of hatching. Because the critical period and PNR can be affected by external factors such as salinity, diluted oxygen, and the food supply, further studies are required to redress the paucity of data relevant to rock bream culture and mass production.

\section{ACK NOWLEDGMENTS}

This research was funded by the Species Conservation and Practical Studies Based on the Tongyeong Marine Living Resources Resarch \& Conservation Center (PO 00110) and Studies of Marine Biodiversity in Korea (PG 48260) from the Korea Institute of Ocean Science \& Technology (KIOST), Republic of Korea. The authors thank the technical staff of the Laboratory for Fishery Genetics and Breeding Science at Korea Maritime and Ocean University, Republic of Korea, for their helpful support, and the anonymous reviewers who greatly improved the quality of this manuscript. All procedures used in this study complied with the current laws of Republic of Korea (Ordinance of Agriculture, Food and Fisheries, No. 1, and that Pertaining to Experimental Animals, No. 9,982).

\section{REFERENCES}

Blaxter JHS, Hempel G (1963) The influence of egg size on herring larvae (Clupea harengus L.). J Cons Perm Int Explor Mer 28:211-240.

Blaxter JHS, Hempel G (1966) Utilisation of yolk by herring larvae. J Mar Biol Assoc UK 46:219-234.

Choi Y, Kim JH, Park JY (2002) Korean Marine Fish. Kyohak. Pub., 384 pp.

Crespo S, Marin de mateo M, Santamaria CA, Sala R, Grau A, Pastor E (2001) Histopathological observations during larval rearing of common dentex Dentex dentex L. (Sparidae). Aquaculure 192:121-132.

Ehrlich KF, Blaxter JHS, Pemberton R (1976) Morphological 
and histological changes during the growth and starvation of herring and plaice larvae. Mar Biol 35:105-118.

Farris D (1960) The effect of three different types of growth curves on estimates of larval fish survival. J Cons Int Explor Mer 25:294-306.

Gerking SD (1994) Feeding Ecology of Fish. Academic Press, London. 156 pp.

Han HK, Lim SG, Kang JH, Choi JW, Gil HW, Cho SH, Lim, SY, Park I-S (2013) Morphometric and histological changes in cyprinid loach, Misgurnus anguillicaudatus, in the early growth period. Dev Reprod 17:187-198.

Hwang HK, Kang YJ, Lee JH, Yang SK (1996) The breeding test of rock bream, Oplegnathus fasciatus. Rep South Fish 381-383.

Johnson G (1989) The biology of fish growth. Can Vet J January 30:82-83.

Kang YJ, Lee SM, Hwang HK, Bae SC (1998) The proper protein and lipid of rock bream, Oplegnathus fasciatus. J Aquacult 11:1-10.

Kim SH, Lee CH, Seo DO, Kim YJ (2002) Basic study about adjustment of sound. 1. The feature of sense of rock bream, Oplegnathus fasciatus. J Fish Sci Tech 35:563-567.

Laurence GC (1974) Growth and survival of haddock, Melanogrammus aeglefinis larvae in relation to planktonic prey concentration. J Fish Res Board Can 31:14151419.

Lee CK, Park I-S, Hur SB (1998) The change of hepatocyte nuclei on red grouper under starvation. J Aquacult 11:11-17.

Lim SG, Han HK, Kang JH, Park HJ, Oh JS, Lim JS, Goo IB, Park I-S (2013) Comparative analysis of the morphometric changes in Ussurian bullhead, Leiocassis ussuriensis, and Korean bullhead, Pseudobagrus fulvidraco, in the early period of growth. Dev Rprod 17:257268.

Love RM (1980) The Chemical Biology of Fishes. Vol 2. Academic Press, London and New York, pp 50-75. May RC (1974) Larval mortality in marine fishes and the critical period concept. In: Blaxter, J.H.S. (ed.), The Early Life History of Fish. Springer-Verlag, New York. 3-19 pp.

Myong JK, Kim HS, Kim BK, Kim YO (1992) The change of trait on olive flounder, Paralichthys olivaceus larve under starvation. J Korean Ichthyol 4:20-28.

Myong JK, Kim JM, Kim YO (1990) The change of trait on red sea bream, Pagrus major, larvae under starvation. J Korean Ichthyol 2:138-148.

Myong JK, Park CW, Kim MS, Kim JM, Kang CB, Kim YO (1997) The change of trait on sea bass, Lateorabrax sp. about early growth stage under starvation - 1. post larvae stage. J Korean Ichthyol 9:15-21.

O`Connell CP (1976) Histological criteria for diagnosing the starving condition in early post yolk sac larvae of the Northern anchovy, Engraulis mordax. Girard J Exp Mar Biol Ecol 25:285-312.

Park I-S, Lee C-K, Lim JH, Kim JH, Kim SU (1998) Effect of starvation on the growth and hepatocyte nuclear size of larval rockfish, Sebastes schlegeli and larval spotted sea bass, Lateolabrax sp. J Aquacult 11:345-352.

Park I-S, Zhang CI (1998) The effect of thyroxine on the growth and yolk resorption of chum salmon, Oncorhynchus keta yolk sac larvae. Isr J Aquacult (Bamidgeh) 50:60-66.

Rust MB (2002) Nutritional physiology. In: Halver, J.E. and Hardy, R.W. (eds.), Fish Nutrition. Academic Press, USA. 44 pp.

Seong KB, Park I-S, Goo IB, Kim DS (2012) Effects of starvation on the morphometric characteristics and histological changes in chum salmon (Oncorhynchus keta) fry. Ocean Polar Res 34:165-173.

Shan X, Quan H, Dou S (2008) Effects of delayed first feeding on growth and survival of rock bream, Oplegnathus fasciatus larvae. Aquaculture 277:14-23.

Strüssmann CA, Takashima F (1990) Hepatocyte nuclear size and nutritional condition of larval pejerrey, Odontesthes bonariensis (Cuvier et Valenciennes). J Fish Biol 36: 59-65. 
Theilacker GH (1978) Effect of starvation on the histological and morphological characteristics of jack mackerel, Trachurus symmetricus larvae. Fish Bull US 76:403414.

Weatherley AH, Gill HS (1987) The Biology of Fish Growth. 4. Protein, Lipid and Caloric Contents. Academic
Press, London, 443 p.

Yin MC, Blaxter JHS (1986) Morphological changes during grow and starvation of larval cod (Gadus morhua L.) and flounder (Platichthys flesus L.). J Exp Mar Biol Ecol 104:21-228. 